\title{
Miten elinikäisestä oppimisesta puhutaan?
}

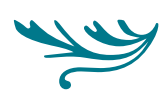

\begin{abstract}
Elinikäistä oppimista koskeva keskustelu liittyy vahvasti muualla yhteiskunnassa käytävään keskusteluun. Käsitteen määrittely riippuu hyvin paljon määrittelijätahosta. Helsingin Sanomien mielipideosaston ja vieraskynäpalstan kirjoituksissa löytyy viisi keskenään aktiivisesti keskustelevaa elinikäisen oppimisen diskurssia.
\end{abstract}

\section{MONITULKINTAINEN ELINIKÄINEN OPPIMINEN}

Pohjoismaisessa elinikäisen oppimisen ensimmäisessä "virallisessa" sukupolvessa 1970-luvulla oli vahvana erityisesti Unescon edustama humanistinen traditio. Siinä elinikäinen oppiminen nähtiin keinona rakentaa sosiaalista tasa-arvoa, parempaa elämää ja elämänlaatua. Ajatuksena oli itsensä kehittäminen: kansalaisia kehotettiin aktiiviseen "itsensä rakentamiseen", jottei heistä tulisi passiivisesti "ulkoisesti rakennettuja”. Myös Pohjoismaissa 1980-luvulla taloudellis-poliittisten ideologioiden ja yhteiskunnallisen ilmapiirin muutokset sysäsivät elinikäisen oppimisen uuteen vaiheeseen, toiseen sukupolveen. Työttömyys kasvoi ja tuottavuus heikkeni. Koulutus ja talous kytkettiin yhä selkeämmin yhteen. Elinikäinen oppiminen alettiin nähdä keinoksi mukauttaa yksilöä yhä nopeampaan yhteiskunnalliseen muu- tokseen. Inhimillisen pääoman tuottajana elinikäisestä oppimisesta tuli taloudellisen kasvun tärkeä osatekijä. (Dehmel 2006, 49-51; Rubenson 2006, 327-330; Tuomisto 2012, 415-427.)

Kjell Rubensonin (2006) mukaan sääntelystä vapautetun kapitalismin sosiaaliset seuraukset näkyivät 1990-luvulta lähtien kasvavina luokkaeroina ja kärjistyvinä sosiaalisina ongelmina, joiden taas pelättiin muodostuvan yhteiskunnille uhaksi. Polarisaatiokehitys on ainakin poliittisessa retoriikassa johtanut elinikäisen oppimisen ideologian pehmentymiseen ja kovan markkinaideologian lieventymiseen. Elinikäisen oppimisen kolmatta sukupolvea onkin kuvattu kahden edellisen sukupolven yhdistelmäksi: markkinat yhä määräävät kehikon, mutta valtion ja yksilön vastuu on tullut hieman näkyvämmäksi. (Emt.; myös Tuomisto 2012.) 
Toisaalta Rubenson (2006) muistuttaa, että elinikäisen oppimisen retoriikan tarkempi tutkiminen ja ymmärtäminen on tuonut skeptisiä äänenpainoja ja kyseenalaistavia mielipiteitä kolmannen sukupolven todellisesta syntymisestä elinikäisen oppimisen julkisessa diskurssissa. Esimerkiksi Bownin (2000, 348) mukaan teknologisen kehityksen myötä oppimisesta on tullut yhä enemmän instituutiosta, ajasta ja paikasta riippumaton kaikki a ikäkausia koskeva välttämättömyys. Oppimisen kenttä on entisestään laajentunut ja elinikäisen oppimisen käsite on sisällöllisesti entistä moniaineksisempi. Bownin mukaan aikaisemmin käsitteeseen sisältyi vahvemmin ajatus yksilön varustautumisesta demokraattiseen elämään (vrt. ensimmäinen sukupolvi), kun se nykyään ymmärretään lähinnä inhimillisenä pääomana ja sijoituksena taloudelliseen kasvuun. Biestan (2006, 169) mukaan käsitteen kompleksisuudesta huolimatta elinikäinen oppiminen liitetään tänä päivänäkin vahvimmin talouden kontekstiin, "tietotalouteen", "oppivaan talouteen", "informaatioon perustuvaan talouteen".

Elinikäinen oppiminen tarkoittaa eri ihmisille ja yhteiskunnallisille toimijoille eri asioita. Monitulkintaisuutensa ansiosta sitä voidaan hyödyntää mitä erilaisimpiin tarkoituksiin poliittisissa diskursseissa ja ideologisissa kamppailuissa (Biesta 2006, 173.) Käsitteen ulkoasukin on vaihdellut eri aikakausina elinikäisestä kasvatuksesta jatkuvaan kasvatukseen ja jaksottaiskoulutukseen (ks. esim. Alanen 1983) sekä elämänlaajuiseen oppimiseen. Käsitteet ja diskurssit ovat mukautuneet ja sekoittuneet kulloinkin vallitseviin yhteiskunnallis-poliittisiin oloihin ja ajan henkeen. Elinikäistä oppimista koskeva keskustelu liittyy vahvasti juuri muualla yhteiskunnassa käytävään keskusteluun ja konstruoituu yhteiskuntapoliittisista konteksteista riippuen eri tavoin. Käsitteen liepeillä puhutaan esimerkiksi oppivista organisaatioista, tietoyhteiskunnasta, riskiyhteiskunnasta erilaisine ongelmineen, työvoiman joustavuuden tarpeesta sekä oppivasta yhteiskunnasta. Olennaista elinikäisen oppimisen määrittelyssä on määrittelijätaho. Esimerkiksi Unesco ja OECD määrittelevät käsitteen omista tarkoitusperistään käsin (ks. esim. Tuomisto 1994, 23-24; Rinne \& Salmi 2000, 149-152; Schuetze
2006, 289-306). Biestan (2006, 173) mukaan on olennaista muistaa, ettei käsitteellä ole koskaan ollut vain yhtä ja kaikkien hyväksymää määritelmää. Se on aina ollut eräänlainen yhdistekäsite, johon useat tahot ja toimijat heijastavat omia toiveitaan ja tavoitteitaan.

\section{TUTKIMUSAINEISTO JA -KYSYMYKSET}

Analysoin seuraavassa empiirisesti, miten sosiaalista todellisuutta elinikäisestä oppimisesta retorisesti konstruoidaan ja millaisia valtasuhteita diskursseista rakentuu suhteessa muihin "kilpaileviin diskursseihin". Käytän aineistona Helsingin Sanomien mielipidesivustoilla ja vieraskynäpalstalla vuonna 2006 julkaistuja kirjoituksia, jotka käsittelevät elinikäistä/ elämänlaajuista kasvatusta/oppimista (ks. Kinnari 2009).

Aineistoa kerätessäni luin vuodelta 2006 jokaisen mielipidetekstin ja vieraskynäpalstan, joista tapauskohtaisen pohdinnan jälkeen valitsin analyysivaiheeseen pääsevät tekstit. Kuuden lukukerran jälkeen aineistoon jäi 127 tekstiä, aineisto kyllääntyi ja jokainen teksti oli perusteltavissa aineistoon ja omaan diskurssiinsa kuuluvaksi. Pilkoin jokaisen diskurssin vielä pienempiin, aineiston jakoa helpottavampiin alaotsikoihin. Tällä tavoin saatoin tuoda enemmän esiin diskurssien rakentaman todellisuuden moni-ilmeisyyttä ja moniulotteisuutta. Alaotsikot helpottivat myös lukemista ja selkeyttivät ajatusta.

Tutkin diskurssianalyysin keinoilla, miten aineiston kirjoituksissa tuotetaan ja rakennetaan sosiaalista todellisuutta elinikäisestä oppimisesta, ja miten erilaiset diskurssit elinikäisestä oppimisesta aktualisoituvat sosiaalisissa käytännöissä (vrt. Jokinen, Juhila \& Suoninen 1993, 17-18, 24-29; Foucault 2005a, 42). Tutkimuksen lähtökohdat nojaavat sosiaalisen konstruktionismin kielikäsitykseen, jolloin kohteena ei ole se, mikä on "totuus", vaan kuinka erilaiset "todellisuudet" elinikäisestä oppimisesta rakentuvat suhteessa muihin ja itseensä (Jokinen, Juhila \& Suoninen 1993, 18; Berger \& Luckmann, 1994, 11-13; Eskola \& Suoranta 1998, 139-141; Johnstone 2002, 30). Toisaalta tutkimukseni tavoite on kiinnittää huomiota siihen, miten elinikäisen oppimisen eri painotuksia perustellaan ontologisella ja universaalilla retoriikalla. Lähtökohtaisesti sosiaaliset ongelmat ja ilmiöt rakentuvat kulttuurisesti ja historialli- 
sesti. (Juhila 2006, 162; Suoninen 2006, 18; Foucault 2005a, 42.)

\section{Miksi Helsingin Sanomat aineistona?}

Viestimet vaikuttavat meihin, mutta myös viestimiin ja viesteihin vaikuttavat monet tekijät. Kuinka puolueeton esimerkiksi lehden mielipideosasto on? Fairclough (1997, 60-64) erottaa kaksi erilaista viestimiin vaikuttavaa tasoa: taloudellisen sekä poliittisen. Lehtikustantamot ovat voittoa tavoittelevia organisaatioita, ja instituutioiden taloudellinen rakenne on niiden käytäntöjä ja tekstejä määräävä tekijä. Näin ajateltuna esimerkiksi tiedotusvälineiden tekstit ovat tehokkaan kulttuuriteollisuuden tuottamia symbolisia hyödykkeitä, jotka toimivat markkinoiden ehdoilla voiton tavoittelussa. Poliittinen taso näkyy Fairclough'n (1997, 62-64) mukaan siinä, että viestimien esittämä tieto (esimerkiksi uutiset) on aina ideologisesti muotoutunut, mihin onkin useissa eri tiedotusvälineitä käsittelevissä tutkimuksissa kiinnitetty huomiota.

Yleisesti ottaen joukkoviestinnän vaikutusten empiirinen tutkimus on vaikeaa. Mitä enemmän asioita on tutkittu, sitä enemmän on löytynyt joukkoviestinnän vaikutuksen kannalta merkityksellisiä tekijöitä. Lähettäjän näkökulmasta vaikutuksen ennakoiminen yksittäisissä ihmisissä on lähes mahdotonta (ks. esim. Kunelius 1997, 118, 127; ks. myös Hemanus 1973, 12-13).

Päädyin aineistonvalinnassa Helsingin Sanomiin sen lähes monopolisen ja valtakunnallisen aseman vuoksi. Lehden levikki on Suomen päivälehdistä ylivoimaisesti suurin (levikki 417548 arkisin ja 476211 sunnuntaisin, Helsingin Sanomien mukaan kokonaislevikki eli lukijamäärä oli 1030000 vuonna 2006). Se on levikiltään myös koko Pohjoismaiden suurin lehti. Suhosen (1994, 70-71) mukaan Helsingin Sanomat ei ole edustava näyte maamme sanomalehdistä saati yleisestä joukkoviestinnästä, mutta juuri se tekee siitä hänen mielestään mielenkiintoisen tutkimuskohteen. Lehdellä on erityisasema suomalaisessa viestintäjulkisuudessa ja yhteiskunnallisen keskustelun ohjaamisessa - tavoittelee se sitä tai ei. Helsingin Sanomien paikkaa julkisuudessa ja erityisesti sanomalehdistön kentällä kuvaavat lehden suuri levikki, toimintaresurssit ja institutionaalinen asema. Kattavuudelle on luonteenomaista myös sen ulottuminen koko maahan.

Lehden mielipideosasto on eräänlainen vallankäytöllinen keskustelutila, jossa kirjoittajat retorisesti konstruoivat omia poliittisia, kulttuurisia, yhteiskunnallisia, sukupuolittuneita sekä alueellisia diskursseja elinikäisestä oppimisesta. Keskustelutilan muotoutumiseen vaikuttaa toki myös Helsingin Sanomien saavuttama asema medioiden ja julkaisujen kentässä. Helsingin Sanomat itsessään on vallankäyttäjä.

\section{Elinikäisen oppimisen rakentuminen vieraskynä- ja mielipidesivustoilla}

Teksteistä nousee viisi keskenään aktiivisesti keskustelevaa elinikäisen oppimisen diskurssia:

1) Uusliberalistisessa diskurssissa elinikäisen oppimisen todellisuus painottuu taloudellisena hallintana tavoitteena innovatiivinen yhteiskunta. Diskurssiin liittyy usein kansallisen kilpailukyvyn retoriikka.

2) Uusliberalismin vastainen diskurssi kritisoi aktiivisesti uusliberalistisen todellisuuden ihmistä hyväksikäyttävää luonnetta, ihmisen riittämättömyyttä ja muutokseen sopeutumisen pakkoa elinikäisenä oppimistehtävänä rakentamatta kuitenkaan vaihtoehtoista todellisuutta.

3) Sivistyksellinen diskurssi kyseenalaistaa uusliberaalin sosiaalisen todellisuuden arvopohjan vaatimalla demokraattista keskustelua "hyvästä elämästä ja yhteiskunnasta”, millaisessa ihmisen tulisi oppia ja mihin sosiaalistua.

4) Funktionalistisessa eli yhteiskuntaan integroivassa diskurssissa elinikäisen oppimisen diskurssi lähentyy uusliberalistista. Se korostaa työn arvoa kansalaisuuden rakentumisessa saaden joskus jopa autoritaarisia piirteitä. Se muistuttaa yhteiskunnan olevan kuin kellokoneisto, johon yksilön on yhtenä rattaana integroiduttava.

5) Yhteiskuntaan kriittisesti suhtautuva diskurssi kyseenalaistaa ennen muuta luterilaisen työmoraalin. Se näyttäytyy vaihtoehtoisena, omia arvoja noudattavana elämään oppimisena, jossa tulevaisuuden yhteiskunta on enemmän ihmisten joustava oppimiskenttä. 
Taulukko 1. Elinikäisen oppimisen diskurssit

aineistossa (lukumäärä ja prosenttiosuus).

\begin{tabular}{|l|c|c|c|c|}
\hline Diskurssin nimi & Kokonaismäärä & Prosenttiosuus & $\begin{array}{c}\text { Asiantuntijoiden } \\
\text { kirjoitukset }\end{array}$ & $\begin{array}{c}\text { Muiden kuin asiantun- } \\
\text { tijoiden kirjoitukset }\end{array}$ \\
\hline Uusliberalistinen diskurssi & 27 & $21 \%$ & 21 & 6 \\
\hline $\begin{array}{l}\text { Uusliberalismin vastainen } \\
\text { diskurssi }\end{array}$ & 37 & $29 \%$ & 16 & 21 \\
\hline Sivistyksellinen diskurssi & 20 & $16 \%$ & 13 & 7 \\
\hline Funktionalistinen diskurssi & 15 & $12 \%$ & 11 & 4 \\
\hline Yhteiskuntakriittinen diskurssi & 28 & $22 \%$ & 18 & 48 \\
\hline Yhteensä & 127 & $100 \%$ & 79 & 4 \\
\hline
\end{tabular}

\section{Diskurssit}

Uusliberalistinen diskurssi osoittautuu aineistossa hegemoniseksi ja retorisesti vahvimmaksi konstruktioksi. Retoriikka nojautuu myös vahvimmin asiantuntijuuteen. Uusliberalistisessa diskurssissa korostuvat asiantuntijat: 78 prosenttia diskurssin teksteistä koostuu asiantuntijoiden kirjoituksista. Asiantuntijuudella tarkoitan tässä yhteydessä henkilöä, joka on lisännyt kirjoitukseensa asiantuntijuutta korostavan tittelin retoriikan ja puhujakategorian vahvistamiseksi. Uusliberalismin vastaisen diskurssin kirjoittajista enemmistö (57\%) on kirjoittajia, joiden teksteissä asemaa kuvaavaa titteliä ei ole.

Myös toinen, funktionaalinen ja yhteiskuntaan integroiva diskurssi paljastuu asiantuntijaenemmistöiseksi. Diskurssin kirjoittajista kolme neljäsosaa (73 $\%)$ nojaa retoriikkansa koulutuksen tai aseman tuomaan statukseen. Ainoastaan uusliberalistisen vastaisessa diskurssissa "tavallisen kansan" tekstejä ilmenee enemmän kuin asiantuntijoiden. Se voi kertoa siitä, että Helsingin Sanomien mielipideosastolle kirjoittavista on huomattava osa erilaisia asiantuntijoita, joiden tekstit myös oletettavasti julkaistaan helpommin kuin pelkällä nimellään kirjoittavien kansalaisten. Toisaalta se voi kertoa myös aiheen ajankohtaisuudesta ja sosiaalisen todellisuuden jakautuneisuudesta. Yhteiskuntakriittisessä diskurssissa kaksi kolmasosaa (64 \%) kirjoittajista on asiantuntijoita. Myös sivistyksellisessä diskurssissa kaksi kolmasosaa (65\%) kirjoittajista nojaa asiantuntijuuteen pohtiessaan "hyvän elämän” kysymyksiä.
Seuraavassa esittelen aineistosta muodostetut viisi diskurssia esimerkkitekstein.

\section{Uusliberalistinen diskurssi}

Perinteiset työpaikat Suomessa ovat häviämässä useimmilta aloilta samalla kun valtion ja kunnan hallinto, liikeyritykset ja teollisuus kansainvälistyvät. Siksi joustavuuden, ajattelukyvyn, johtamistaitojen ja innovaatioajattelun opettaminen ja oppiminen tulevat keskeisiksi kilpailutekijöiksi sijoituttaessa uusille työmarkkinoille. Viestintävalmiudet ja -taidot ovat oleellinen osa uuden työntekijän menestystarinaa kun hän myy itsensä ensimmäiseen työpaikkaansa. (HS, Mielipide 25.5.06)

Vieraskynä- ja mielipideosastojen tekstit osoittavat, että uusliberaalin ajattelun mukainen elinikäinen oppiminen muodostuu teksteissä yhdeksi tärkeimmistä yksilön ja yhteiskunnallisen menestymisen elementeistä. Uusliberalistinen diskurssi näyttäytyy automaattisena, vaihtoehdottomana tulevaisuuden tai nykyisyyden maailmana, jolloin vapaa markkinatalous, kilpailukyky, innovointi ja etenkin globalisaatio sanelevat yksilöiden toimintamahdollisuudet ja velvoitteet sosiaalisen todellisuuden ja toiminnan kentillä. Kyseinen diskurssi on aineiston vahvin ja hegemonisin elinikäisen oppimisen diskurssi, johon muut diskurssit itsensä suhteuttavat, joko sitä vastaan hyökäten ja sen edustaman todellisuuden kiistäen tai siihen yhtyen. Diskurssien hegemonisoitumista analysoitaessa tekstien määrää ei välttämättä ole olen- 
naisin asia. Tärkein on sen nimenomainen vaihtoehdottomuus ja itsestäänselvyys (vrt. Jokinen \& Juhila 1993, 81). Kiinnostus kohdistuu tällöin siihen, miten valtasuhteet saavat totuudellisen aseman. Erityisen mielenkiintoinen asia ovat kulttuuriset itsestäänselvyydet, kuten "luonnollisiksi" ja kyseenalaistamattomiksi muotoutuneet diskurssit, jotka syövät elintilaa muunlaiselta ajattelulta (Jokinen ym. 1993, 75-77).

Diskurssin todellisuus näyttäytyy usein yksiulotteisesti talouden reunaehtojen mukaisena, jolloin markkinoiden ensisijaisuuteen perustuva ajatusmaailma ulottuu ihmisten koko elämänpiiriin. Esimerkiksi moniosaaminen ja laaja-alaisuus saavat väistyä erikoistumisen tieltä, kun ne palvelevat taloutta ja tehokkuutta. Yksilön elinikäiseksi oppimistehtäväksi tulee erikoistumalla sopeutua vallitsevaan kilpailuyhteiskuntaan. Luovat ja erikoistuneet yksilöt vievät yhteiskuntaa "eteenpäin". Usein tätä perustellaan meretoriikalla (ks. Jokinen 2006), kaikkia väestöryhmiä ja yhteiskunnallisia toimijoita yhteisesti hyödyttävän kansallisen kilpailukyvyn ajatuksella.

Innovaatioajattelu ja innovaatio-sanan toistaminen diskurssin kirjoituksissa rakentaa uskoa edistykseen, ja varsinkin teknologista kehitystä ja sen tuomaa hyvinvointia korostetaan diskurssissa ahkerasti. Elinikäinen oppiminen esitetään uudenlaisena ajattelutapana, jolloin tärkeintä olisi pyrkiä innovatiiviseen, maailmaa murtavaan ajattelutapaan. Teknisen osaamisen korostaminen diskurssissa tarkoittaa teknokraattisen ajattelutavan leviämistä niin sanotuille ei-teknisille alueille, ja teknisestä osaamisesta tulee toimialasta riippumatta jokaisen kansalaisen velvollisuus.

Uusliberalistisen diskurssin todellisuuden rakentuminen elinikäisestä oppimisesta korostaa yksilöllisyyttä, erottautumista ja negatiivista vapauskäsitettä (vrt. Räsänen 2007), vaikka toisaalta samaan aikaan vaaditaan yhteneväisiä ominaisuuksia (innovatiivisuus, joustavuus, viestintätaidot) ja ennen kaikkea näiden ominaisuuksien esille panoa eli itsen markkinointia. Taloudellinen ajattelutapa korostaa sopeutumista ja menestymistä. Elinikäisestä oppimisesta muodostuu (itse)hallintakeino, jonka avulla ihmiset voivat pitää itsensä yksiulotteisen maailman kehityksessä mukana. Elinikäinen oppiminen ei diskurssissa enää pelkästään integroi uusliberaaliin yhteiskuntaan, vaan myös hallinnoi ihmisiä pysymään järjestelmän sisällä.

\section{Uusliberalismin vastainen diskurssi}

Tulosjohtaminen, elämänhallinta ja itsensä johtaminen - sekä talouskasvun vaatimus - on ovelasti niputettu samaan pakettiin: yhdellä ja samalla menetelmällä ratkeavat niin fyysisen kuin henkisenkin hyvinvoinnin ongelmat. Talouskasvu merkitsee lähes samaa kuin henkinen kasvu... Itseään kunnioittava ihminen ei kuitenkaan ikuisesti alistu tulosjohdettavaksi eikä - palkattavaksi... Miksi hän ei käyttäisi vapauttaan ja säilyttäisi itsekunnioitustaan, sen sijaan että myy itsensä orjaksi epäinhimillisille työmarkkinoille? (HS, Mielipide 2.1.06)

Uusliberalismin vastainen diskurssi hyökkää vahvoin sanankääntein vaihtoehdottoman talouden determinoivan maailman kimppuun ja väittelee kiivaasti uusliberaalia todellisuutta rakentavan diskurssin kanssa. Kirjoitukset kritisoivat uusliberalismin kilpailuun perustuvaa näkemystä, jossa ihmisen elinikäisen oppimisen osaksi muodostuu välineellinen sopeutuminen epäinhimillisessä ja egoistisessa sosiaalisessa todellisuudessa. Tekstit rakentavat kuvaa, jonka mukaan muutos on mahdollinen, eikä elinikäisen oppimisen tarvitse rakentua vaihtoehdottoman uusliberalistisen diskurssin mukaisesti. Kirjoitukset rakentavat vakavaa kritiikkiä "todellisuudestamme" ja pyrkivät paljastamaan sen kahlitsevia rakenteita emansipoimalla ihmisiä talouden vallan tiedostamiseen. Se ei kuitenkaan rakenna vaihtoehtoista maailmaa uusliberalistisen diskurssin rinnalle.

Diskurssin sosiaalisessa todellisuudessa kritisoidaan aika ajoin hyvin kyynisestikin yhteiskunnan arvopohjaa ja ihmiskäsitystä, jonka mukaan yhteiskunnasta on tullut keskinäisen kilpailun viidakko. Osa kirjoituksista on tunnepitoisia, ääri-ilmaisullisia (vrt. Jokinen 2006) ja retorisesti monipuolisia, kun ne luovat kuvaa maailmasta synkkänä, turhauttavana, materialismin hallitsemana paikkana. Kirjoituksissa syntyy vallankäytöllinen näkökulma, jonka mukaan uusliberalismi ideologiana käyttää ihmisiä hyväkseen pakottamalla heidät sopeutumaan vallitseviin 
oloihin. Vaikka diskurssissa ei suoranaisesti luoda toisenlaista todellisuutta, pyrkivät kirjoitukset kriittisesti muistuttamaan ihmisen olevan moniulotteinen olento, jonka henkisyyttä joka paikkaan tunkeutuva arvottaminen ja kilpailuttaminen murtavat. Elinikäisestä oppimisesta tulee uusliberalistisessa todellisuudessa yksilön jatkuvan riittämättömyyden aiheuttaja, kun nopeasti kehittyvässä yhteiskunnassa myös ihmisen on jatkuvasti viritettävä itseään entistä toimivammaksi kokonaisuudeksi. Kirjoitusten rakentaman todellisuuden mukaan ihmiset joutuvat tähän ulkoa saneltuun pakkoon yhä nuorempina elinikäisen oppimisen vaatimusten ulottuessa aina lapsuuteen asti. Elinikäisellä oppimisella ei ole sellaista täydellisyyden tilaa, jossa ihminen voisi tuntea itsensä "täysin oppineeksi". Elinikäisen oppimisen vaatimukset aiheuttavat pikemminkin loputonta riittämättömyyden tunnetta ja jatkuvat ihmisten väliset vertailut ja mahdolliset epäonnistumiset häpeää (vrt. Jokisaari, 2004). Toisaalta jatkuva uuden oppiminenkaan ei takaa yhteiskunnallista onnistumista, koska menestyneille tarjolla olevia paikkoja on aina rajoitetusti. Tässä mielessä uusliberalistisen diskurssin tarjoama elinikäisen oppimisen ilosanoma paljastuu kuplaksi. Se vastaisessa diskurssissa ei silti pelkästään rakenneta passiivista negatiivista todellisuutta, vaan ihmiset haluttaisiin saada emansipaation kautta kyseenalaistamaan uusliberalistinen vaihtoehdottomuus.

\section{Sivistyksellinen diskurssi}

Raskaan työn raataja on kanonisoitu suomalaiseen kulttuuriin ja sitä kautta kansan mieleen - itsensä uhraaminen työlle on nähty sankarillisena ja yhteistyön kannalta välttämättömänä tekona... Kumppanin, lasten ja ystävien kanssa vietetty aika, harrastukset, taiteesta nauttiminen ja sen luominen sekä itsensä sivistäminen uhrataan työn alttarille. Ihmisten tulisi pysähtyä ja miettiä, mitä työtä oikein haluavat - tulisiko sen olla heidän elämässään rengin vai isännän roolissa? (HS, Mielipide 14.10.06)

Sivistyksellinen diskurssi eroaa muista diskursseista siinä, ettei sillä ole suoranaista vastinparia. Se on aineiston itsenäisin diskurssi. Diskurssissa esitetään kysymyksiä hyvästä elämästä ja vaihtoehtoisesta maailmasta, jossa ihmisten hyvinvointi on etusijalla. Sivistyksellisyys, solidaarisuus, monikulttuurisuus, taiteellisuus ja toisten huomioonottaminen nähdään ihmisyyteen kuuluvina ominaisuuksina, joita tulisi opetella ja harjoittaa. Sivistyksellisessä diskurssissa elinikäinen oppiminen rakentuu elämänfilosofisena ideologiana ihmisyyteen kasvamisena niin yksilönä kuin yhteisönä. Se muistuttaa näkemyksiltään elinikäisen oppimisen historiallisia juuria. Toisaalta, vaikka diskurssissa pyritään luomaan itsenäistä kuvaa elinikäisestä oppimisesta, talouden korostuminen nähdään tekstikatkelmissa usein vallitsevana sosiaalisena todellisuutena, jolloin kokonaisvaltaisen sivistyksen tarvetta perustellaan myös kilpailukyvyn kannalta. Diskurssin todellisuudessa pelkän sivistyksen tai ihmisten hyvinvoinnin korostaminen ei riitä, vaan myös esimerkiksi taiteiden aseman tärkeyttä perustellaan sillä, että kulttuurin ja taiteiden vaaliminen edesauttavat innovatiivisuuden ja luovan ajattelun kehittymistä.

Diskurssissa kyseenalaistetaan sosiaalisen todellisuuden perusta ja vaaditaan kriittistä keskustelua muun muassa hyvästä elämästä, sivistyksestä ja monikulttuurisuudesta. Erityisesti diskurssissa pyritään herättelemään ihmiset kysymään, millaisiin arvoihin kansalaisten tulisi yhteiskuntaan kasvaessaan sosiaalistua. Tekstien todellisuudet rakentavat vaihtoehtoja uusliberaalille vaihtoehdottomuudelle, korostamalla sivistyksen ja tiedon merkitystä ihmisten henkilökohtaiselle vapaudelle ja keskinäiselle solidaarisuudelle. Uusia innovaatioita ei tule nähdä vain taloudellisen hyödyn tuojina tai keksimisen välttämättömyytenä - siihen elämä on liian arvokas. Tärkeämpänä tehtävänä elämässä tulisi olla oppia etsimään niitä hyvän elämän tikapuita, joita sivistyksellisyys ja tietoisuuteen herääminen edellyttävät.

Toisaalta diskurssissa rakennetaan myös märittelyä siitä, mitä ihminen on. Ihminen nähdään kokonaisuutena, jonka olemukseen kuuluu altruistinen toiminta ja empatia. Diskurssin mukaan ihminen ei ole uusliberalistisesti taloudellisten lainalaisuuksien mukainen olento, jonka pyrkimys on ainoastaan maksimoida omaa hyötyään. Käsityksen eroavaisuus ihmisyyden olemuksesta muuttaa myös näkemystä elinikäisestä oppimisesta. Koska ihmisen olemus ja 
se, millaiseksi ihmisen pitäisi tulla, oletetaan essentiaalisesti, elinikäinen oppiminen muodostuu diskurssissa menetelmäksi tämän tavoitteen saavuttamiseksi. Elinikäinen oppiminen ei ilmene kaikissa diskurssin teksteissä demokraattisena pohdintana, mitä sen tulisi käsittää ja mihin sen tulisi perustua, vaan humanistinen ihmiskäsitys otetaan osissa teksteistä vaihtoehdottomana käsityksenä ihmisyydestä kohti parempaa tulevaisuutta ja ihmisten onnellisuutta.

\section{Funktionalistinen ja yhteiskuntaan integroiva diskurssi}

Töihin meno koetaan vapaa-aikaa liikaa rajoittavana tai sitten sosiaalietuuksia liikaa kaventavana vaihtoehtona, jonka vuoksi nykyistä olotilaa ei haluta muuttaa. Jotain on pahasti arvomaailmassa vialla, kun eivät edes vakituiset palkkatyötkään tunnu kiinnostavan, koulutusvaihtoehdoista puhumattakaan... Luulisi, että työelämään paluu olisi tavoiteltava asia, jonka eteen jokainen olisi valmis ponnistelemaan ja etsimään uusia työllistymisväyliä... On vain ajan kysymys, miten pitkään yhteiskuntamme pystyy elättämään tällaista marginalisoitunutta ryhmää, jonka pitkäaikaistyöttömyys on omasta työkokemuksesta katsottuna mieluumminkin itse valittua kuin kohtalonomaista. (HS, Mielipide 5.3.06)

Jos uusliberalistinen ja uusliberalismin vastainen diskurssi rakentuvat toistensa vastinpareina, samoin tekevät myös funktionalistinen ja yhteiskuntaan integroiva diskurssi sekä yhteiskuntaan kriittisesti suhtautuva diskurssi. Ensimmäiseksi mainittu muistuttaa läheisesti uusliberaalia diskurssia, jossa ihmiset sosiaalistetaan vallitsevaan vaihtoehdottomaan todellisuuteen, joskus jopa pakolla uhkaillen. Elinikäinen oppiminen kiinnittyy yhteiskuntaan ja sen arvoihin kasvamisena ja sosiaalistumisena. Yhteiskunta nähdään modernin yhteiskunnan mukaisesti tarkoin määriteltynä kellokoneistona (vrt. Kiilakoski \& Hautakangas 2007), jonka toimintaan jokaisen on osallistuttava. Postmodernia pirstaloituneisuutta ja moniarvoisuutta ja -äänisyyttä ei juuri rakenneta, vaan yhteiskunta rakentuu kiinteänä kokonaisuutena, jolla on yksi ydin. Kansalaisuus ja ihmisarvo yhteisössä toteutuvat työn kautta, jolloin elinikäisen oppimisen tehtäväksi muodostuu pysyminen työmarkkinoilla, tilanteen mukaan työvoimakoulutuksen, henkilöstökoulutuksen tai muun lisä- ja uudelleen koulutuksen avulla. Elinikäisen oppimisen voi nähdä diskurssissa vallankäytöllisenä menetelmänä, jonka avulla korostetaan työn arvostusta ihmisen elämänkaaressa - kulttuuriperinnön siirtäminen, yhteiskunnan jatkuvuuden turvaaminen ja yksilön sosialisaatio ovat yhteisiä tekijöitä, kun luodaan ja ylläpidetään yhteiskunnallista vakautta (ks. Antikainen, Rinne \& Koski 2006, 153).

Diskurssin todellisuus kiinnittyy avoimesti järjestyksen ja kurin periaatteisiin, joissa ihmiset retorisesti kategorisoidaan (vrt. Jokinen 2006) kunnollisiin ja kunniattomiin, moraalisen oikean ja väärän nimissä. Kirjoitukset rakentavat elinikäistä oppimista puhtaasti hierarkkisen yhteiskunnan vallankäytöllisenä menetelmänä, jotta yksilö saataisiin yhteiskunnallisen kontrollin piiriin. Työ kuuluu diskurssin todellisuudessa ihmisen kansalaisvelvollisuuksiin ja on elämänsisällöllinen itseisarvo. Kirjoitusten todellisuuden mukaan on yksittäisen ihmisen henkilökohtainen valinta tai heikkous, jos hän ei noudata tätä periaatetta elämässään. Kirjoitukset riitelevät uusliberalistisen vastaisen diskurssin todellisuuden kanssa, jossa useat kirjoittajat rakentavat epätoivoista kuvaa turhuuden täyttämästä elämästä, jossa elinikäisen oppimisen ilosanoma ei ole palauttanut ihmisiä kaiken tiedon päivittämisenkään jälkeen takaisin työelämään. Diskurssissa luodaan avoimesti pakkokeinoja. Kirjoitusten luoman todellisuuden mukaan osa ihmistä on jo syntyessään lahjattomampia kuin toiset. Elämä on kenties runnellut heitä tai he ovat muuten vain haluttomampia integroitumaan yhteiskunnan sääntöihin. Kirjoitukset luovat kuvaa autoritäärisestä yhteiskunnasta, jossa elinikäinen oppiminen palvelee sopeutumista ja vallitsevan yhteiskunnan arvojen sisäistämistä jopa indoktrinaation, propagandan ja pakkokeinojen avulla.

Toisaalta elinikäinen oppiminen syntyy kirjoituksissa emansipaation kautta. Se pyrkii aktivoimaan yhteiskunnasta syrjäytyneet, kuten työttömät, takaisin yhteiskuntaan motivoimalla heitä ja huolehtimalla heidän tulevaisuudensuunnitelmistaan. Todellisuuden voi nähdä auttamisenhaluna, yksilön palauttamisena toimintakuntoon, jolloin samalla edistetään 
kansallista hyvinvointia. Tällainen todellisuus voi olla myös kommunitaristista - yhteisiä arvoja ja hyveitä korostavaa. Todellisuus voi rakentua silloin myös eräänlaisena "enemmistödiktatuurina", jolloin elinikäinen oppiminen palvelee vallankäytöllisenä menetelmänä "yhteisesti sovittuja arvoja" yksilön sosiaalistamisprosessissa yhteiskunnan jäseneksi.

\section{Yhteiskuntaan kriittisesti suhtautuva diskurssi}

Työtehtävien katkoksissa työvoima voi vaihtaa maisemaa tai suunnata elämänsä uudelleen (ns. elinikäinen oppiminen)... Kun rahan yleinen liikekannallepano on ensimmäinen arvo, on parempi pitää ihmiset töissä kuin antaa heille mahdollisuuksia tehdä mitä tahansa itselle ja yhteisölle merkityksellistä. Oikeutus haetaan moraalisista syistä. Työ tekee vapaaksi. Perustulon vastikkeettomuus takaisi, ettei mitä tahansa työtä tarvitsisi ottaa vastaan, ei varsinkaan mihin hintaan tahansa. Työn ulkopuolinen aika palkittaisiin aikana, jona uusi tieto ja persoonalliset kyvyt kehittyvät... Nyt persoonallisuuden astuminen tuotantoon tarkoittaa suurille massoille vain persoonallista riippuvuussuhdetta työnantajaan (ns. paikallinen sopiminen). (HS, Mielipide 1.9.06)

Diskurssi luo lähes päinvastaista todellisuutta elinikäisestä oppimisesta kuin yhteiskuntaan integroiva diskurssi. Käsitys työn arvoon kasvamisesta kyseenalaistetaan. Samoin rakennetaan tiedon olemuksen demokraattista luonnetta kansalaisuuden ja vaikuttamisen kysymyksissä, jolloin keskustelemattomuus elinikäisen oppimisen eri diskursseista nähdään riittämättömänä. Elinikäinen oppiminen ei näyttäydy diskurssissa jäykkärakenteisena, vaihtoehdottomana kokonaisuutena, johon yksilön yhteiskuntansa jäsenenä tulisi sosiaalistua. Todellisuus rakentuu enemmänkin yksilökeskeisenä, postmodernina pirstaloitumisena, jossa korostetaan yksilöllistä mielenkiintoa ja vapautta yhteisöllisen arvopaineen sijaan. Toisaalta tekstit pyrkivät puolustamaan myös avoimen kansallista demokratiaa kritisoimalla elinikäisen oppimisen kasautumista vain eliitin osaksi, luomalla näin yhteiskuntaan uudenlaista vallanjakoa tasa-arvon nimissä.

Diskurssin kirjoitusten todellisuudet suuntautuvat tulevaisuuteen ja luovat uhkakuvaa maailmasta, jossa koulutus kasautuu niille, joilla sitä on eniten (yhteiskuntaluokka, sukupuoli, jne.). Retoriikan mukaan näennäisen mahdollisuuksien tasa-arvon yhteiskunnassa eriarvoisuus lopettaa hyvinvointivaltioajattelun, jolloin elinikäinen oppiminen jää eliitin etuoikeudeksi. Tieto on valtaa, ja elinikäinen oppiminen muuntautuu yhteiskunnallista eriarvoisuutta ja vallankäyttöä rakentavaksi tekijäksi sekä vallankäytölliseksi propagandavälineeksi. Kirjoitukset pyrkivät paljastamaan sosiaalisen todellisuutemme "sudenkuoppia” luomalla kuvaa yhteiskunnasta, jossa vääränlaisella vallankäytöllisellä toiminnalla kavennetaan kansalaisyhteiskunnan demokraattista pohjaa. Sokea usko elinikäisen oppimisen yhteistä hyvää tuottavaan apuun saattaa tietämättään toimia piiloisena vallankäytöllisenä vaikuttajana, diskurssissa varoitetaan.

Diskurssissa rakennetaan myös kriittistä ja yhteiskunnan arvopohjaa kyseenalaistavaa todellisuutta yhteiskuntaan sosiaalistumisesta. Diskurssin todellisuus lähenee keskustelullaan uusliberalismin vastaista ja sivistyksellistä diskurssia. Luterilainen työmoraali eli ahkera ja tunnollinen työnteko, ponnistelu, velvollisuudentunto työtä kohtaan on se arvopohja, jota vastaan tekstikatkelmat pyrkivät hyökkäämään ja vapaus (vapaus työstä) se retorinen konstruktio, joka toimii perusteluna. Ihmisten "todelliset elämän motiivit" piilevät muualla kuin jatkuvassa työelämän uusien toimintatapojen oppimisessa, ja ihmiset haluaisivat vapautua systeeminsä herruudesta, mutta sosiaalinen paine ja yhteiskunnan elinikäinen integraatio aiheuttavat sen, että ihmiset heräävät usein liian myöhään ymmärtämään, mikä on elämässä elämänmittaisen oppimisen ja elämisen arvoista. Tässä mielessä kirjoitusten todellisuudet lähenevät ja limittyvät sivistyksellisen diskurssin kanssa pohdinnalla siitä, mihin elinikäisen oppimisen arvopohjan tulisi suuntautua. Kirjoituksissa ei varsinaisesti rakenneta kysymyksiä siitä, mitä hyvä elämä pitää sisällään, vaan postmodernimaisesti ja eksistentiaalisesti uskotaan yksilön löytävän henkilökohtaisen tien, johon hän vapautensa käyttää. Tärkeimpänä elinikäisenä oppimistehtävänä rakentuu subjektiivinen ajatus siitä, että yksilöt haluavat elämältään muutakin kuin työtä, ja tämän suuntaiseen arvopohjaan yhteiskunnan tulisi muuntautua. 


\section{ELINIKÄINEN OPPIMINEN - UUSLIBERALISTISEN TODELLISUUDEN HALLINTAKEINO?}

Elinikäistä oppimista pidetään ratkaisuna eri maiden kansallisessa ja kansainvälisissä politiikassa talouden jatkuvan kasvun vaatimukseen, globalisaation aiheuttamaan sosiaaliseen paineeseen ja eriarvoisuuteen sekä epävarmuuden sietämiseen. Jotta taloudet säilyisivät kilpailukykyisinä ympäri maailmaa, on niiden elinikäisen oppimisen politiikan ja retoriikan mukaan liityttävä mukaan kilpailuun oppivasta yhteiskunnasta tai ne ovat kadotettuja menetykseen. (Hinchliffe 2006, 93-98; Nicoll \& Fejes 2008, 1-4; Silvennoinen 2011, 69.) Foucault 'laisittain ajatellen elinikäinen oppiminen edustaa yhtä muotoa yksilöiden hallinnasta suhteessa yhteisöön (Olssen 2008, 37). Hallinta voidaan määritellä suunnitelmalliseksi, pitkäjänteiseksi ja vakiintuneeksi vallankäytöksi. Vallankäyttö vakiintuu hallinnaksi, kun käytännöt synnyttävät ja pitävät yllä suunnitelmallisia ja pitkäjännitteisiä valtasuhteita (Foucault 1995, 211; Alhanen 2007, 124-125). Hallinta on siis tietynlainen vallanharjoittamisen tapa, joka foucault 'laisen ajattelun mukaan käsitetään yleiseksi ihmisjoukkojen, -yhteisöjen ja -yksilöiden käyttäytymisen ja toiminnan johtamiseksi ja ohjaamiseksi (Helén 2004, 208-209; Rose \& Miller 2010, 16-17). Tässä suhteessa elinikäinen oppiminen muodostaa Olssenin $(2008,37)$ mielestä selvästi uusliberalistisen hallinnan muodon. Hänen mukaansa Euroopan komissio näkee elinikäisen oppimisen tärkeänä poliittisena strategiana kansallisuuden, sosiaalisen koheesion, työvoiman ja yksilöllisen suorittamisen kehitykselle.

Huomionarvoista hallinnan ymmärtämisessä on, että se kohdistuu paitsi toisiin, myös itseen. Näin ollen hallinnan pariin kuuluu myös itsehallinta eli etiikka (Helén 2004, 208-209; Rose \& Miller 2010, 16-17). Elinikäisestä oppimisesta on sanottukin tulleen itsesäätelyn pedagogiikkaa (vrt. Hinchliffe 2006, 93-98; Nicoll \& Fejes 2008, 1-4). Näin ollen alun perin emansipatorisena ideaalina syntynyt näkemys elinikäisestä oppimisesta muuttuu markkinoiden muodostamaksi rangaistukseksi ja samalla itsensä kehittäminen muuttuu itsensä tarkkailuksi ja rankaisuksi, kun markkinoiden imperatiivit tunkeutuvat yksilöiden kasvatuksellisiin ja koulutuksellisiin sekä eettisiin ideaaleihin (Rose 1998; Hinchliffe 2006, 96-97). Keskeistä todellisuuden rakentumisesta on huomata, ettei hallinnan vakiintuminen tarkoita pysyvää alistumista, vaan hallintaa on jatkuvasti ylläpidettävä käytännöillä, jotta valtasuhteet pysyvät yllä. Kun valtasuhteet tällä tavoin vakiintuvat käytännössä hallinnaksi, ne tulevat suhteellisen riippumattomaksi siitä, mitkä ovat yksilöiden päämäärät ja keitä valtasuhteiden osapuolet ovat ja mihin he pyrkivät. Yksilöt voivat pyrkiä vaikuttamaan siihen, mitä valtasuhteita muodostuu, mutta kun valtasuhteet ovat vakiintuneet hallinnaksi, yksilöiden päämäärien merkitys vähenee. Foucault määritteleekin, että valta on "intentionaalista, mutta ei-subjektiivista". Kun esimerkiksi politiikka ja politikointi, hallintojärjestelyt, jatkuva kouluttautuminen ja elinikäinen oppiminen, organisaatioiden johtamistavat,

\section{YKSILÖT}

HALUAVAT

MUUTAKIN

KUIN TYÖT̈̈.
EL ̈̈MÄLT $\ddot{A} \ddot{N}$ ohjaavan neuvonnan käytännöt ja psykoterapia käsitetään hallinnaksi, niitä tarkastellaan tekniikkoina ja strategioina. Ne muovaavat ja ohjaavat erilaisia keinoja, joiden mukaan ihmiset kokoavat käyttäytymistään yhtenäiseksi. (Helén 1994, 279; Helén 2004, 209-210; Foucault 2005b, 275-279; Alhanen 2007, 126-128.)

Uusliberalismin tarkoitus on ollut antaa ihmisille vapaus valita oma yhteiskunnallinen tie, jolloin ihmiset voisivat vapaasti valita arvomaailmansa (vrt. negatiivinen vapauskäsitys) ja individualistiset mielihalunsa, kunhan eivät loukkaa muita. Näin menestystä saaneet saavat tunteen onnistumisesta, omasta kyvykkyydestä suhteessa toisiin ja siitä, että ovat "vapaasti" valinneet tiensä yhteiskunnassa. Rosen (1998) mukaan kyse on "eettisestä hallinnasta" ja vallan sekä vapauden suhteesta. Termiä "valta" ei käytetä, mutta se ilmenee vastuullisen vapauden välttämättömänä kääntöpuolena. Vapaus ei ole vain yksilön itsehallintaa vaan samanaikaisesti erilaisten yhteisöllisten arvojen hyväksyntää ja näin ollen yksilön tahdonalaista alistumista tiettyjen arvojen valtamuodostelman valtaan. 
Vaikka Helsingin Sanomien yhden vuoden aineistoa ei voida yleistää, voi teksteistä saada suuntaa antavaa, koko kulttuuri-ilmapiiriä koskevaa tietoa. Aspin \& Chapman (2000, 12-17; ks. myös Biesta 2006, 173-178) erottavat kolme elinikäisen oppimisen tehtävää: taloudellisen, henkilökohtaisen ja demokraattisen. Kyseiset elinikäiset oppimisen funktionaaliset tasot erottuvat aineistossa. Sivistyksellisen diskurssin rakentama todellisuus muistuttaa läheisesti elinikäisen oppimisen henkilökohtaista funktiota. Demokraattinen funktio syntyy osittain yhteiskuntakriittisen ja sivistyksellisen diskurssitodellisuuden funktiona, keskusteluna todellisuutemme rakenteista ja elinikäisen oppimisen funktiosta. Elinikäisen oppimisen taloudellinen funktio näkyy aineistossa vahvimpana - tosin eri diskursseissa erilaisissa todellisuuksissa. Vaikka taloudellinen funktio rakentuu näistä kolmesta funktiosta diskursseissa vahvimpana, ei se muodosta aineiston todellisuudessa lainkaan ristiriidatonta kokonaisuutta. Elinikäinen oppiminen on houkuttelevaa, sillä se tarjoaa mahdollisuuden subjektiiviseen menestymiseen. Toisaalta se saattaa myös rakentaa ja ylläpitää yhteiskunnallista polarisaatiota ja vallanjakoa. Jotkut ihmiset voivat ajautua tällaisessa sosiaalisessa todellisuudessa vaihtoehdottomaan, ylhäältä päin määrättyyn elinikäiseen oppimiseen, jolloin elinikäinen oppiminen voi muodostua foucault 'laisittain yksilön itsesäätelyksi ja "arvonormalisoijaksi”, riittämättömyyden tunteen lisääjäksi (vrt. Husa 2003, 68-73 vrt. Saari, 2006). Näin ollen myös vaihtoehtoisen todellisuusmallin valitseminen käy yksilölle mahdottomaksi ja "aktiivinen kansalaisuus" taipuu erinäisten "lainalaisuuksien alle".

Elinikäisen oppimisen vallankäyttö ja hallinta, arvot ja etiikka sekä intressiryhmät sen sosiaalisessa verkostossa ovat erittäin tarpeellisia tutkimuskohteita. Tutkimuksella voitaisiin ehkä purkaa sitä mahdollista käytäntöä, jossa elinikäisestä oppimisesta muodostuu orwellilainen doublethink-termi, jolloin käsitteellä tarkoitetaankin juuri jotain päinvastaista kuin mitä sillä on totuttu tarkoittamaan. Tällaisen positiivisen retoriikan avulla luodun käsitteen taakse piiloutuvan sosiaalisen todellisuuden paljastamiseen tulisi demokraattisessa yhteiskunnassa pyrkiä.

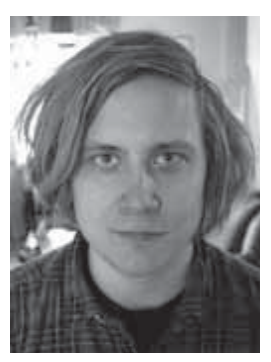

Heikki Kinnari

KM, tohtorikoulutettava

Turun yliopisto,

kasvatustieteen laitos

\section{KIRJALLISUUS}

Alanen, A. (1983). Elinikäinen kasvatus - jatkuva kasvatus - jaksottaiskoulutus. Teoksessa A. Alanen \& Sihvonen, J. (toim.) Elinikäinen kasvatus. Gaudeamus: Helsinki. 40-104.

Alhanen, K. (2007). Käytännöt ja ajattelu Michel Foucault'n filosofiassa. Helsinki: Gaudeamus.

Antikainen, A., Rinne, R. \& Koski, L. (2006). Kasvatussosiologia. Helsinki: WSOY.

Aspin, D.N. \& Chapman, J.D. (2000). Lifelong Learning. Concepts and Conceptions. International journal of lifelong education 19(1). 2-19.

Berger, P.L. \& Luckmann, T. (1994). Todellisuuden sosiaalinen rakentuminen. Tiedonsosiologinen tutkielma. Suom. V. Raskila. Helsinki: Gaudeamus.

Biesta, G. (2006). What's the point of Lifelong Learning if Lifelong Learning Has No Point? On the Democratic Deficit of Policies for Lifelong Learning. European Educational Research Journal 5(3-4). 169-180.

Bown, L. (2000). Lifelong Learning: ideas and achievements at the threshold of the twenty-first century. Compare, 30(3), 341-351.

Eskola, J. \& Suoranta, J. (1998). Johdatus laadulliseen tutkimukseen. Tampere: Vastapaino.

Fairclough, N. (1997). Miten media puhuu. Suom. Virpi Blom \& Kaarina Hazard. Tampere: Vastapaino.

Foucault, M. (1995). Power. Essential works of Foucault 1954-1984. Toim. J.D. Faubion. Käänt. R. Hurley. New York: The New Press.

Foucault, M. (2005a). Tiedon arkeologia. Suom. Tapani Kilpeläinen. Tampere: Vastapaino.

Foucault, M. (2005b). Tarkkailla ja rangaista. Suom. Eevi Nivanka. Helsinki: Otava.

Helén, I. (1994). Michel Foucault'n valta-analytiikka. Teoksessa Heiskala, R. (toim.) Sosiologisen teorian nykysuuntauksia. Tampere: Gaudeamus. 270-315.

Helén, I. (2004). Hyvinvointi, vapaus ja elämän politiikka: foucaultlainen hallinnan analytiikka. Teoksessa Rahkonen, K (toim.) Sosiologisia nykykeskusteluja. Helsinki: Gaudeamus. 
Hemánus, P. (1973). Joukkotiedotus piilovaikuttajana. Helsinki: Otava.

Hinchliffe, G. (2006). Re-thinking lifelong learning. Studies in Philosophy and Education, 25(1-2), 93-109.

Husa, S. (2003). Michel Foucault - Mikrovalta, kasvatus ja normalisoiminen. Teoksessa T. Aittola Kasvatussosiologian teoreetikoita. Helsinki: Gaudeamus, 58-80.

Johnstone, B. (2002). Discourse analysis. Oxford: Blackwell publishing.

Jokinen, A., Juhila, K. \& Suoninen, E. (1993). Diskursiivinen maailma. Teoreettiset lähtökohdat ja analyyttiset käsitteet. Teoksessa A. Jokinen, K. Juhila \& E. Suoninen Diskurssianalyysin aakkoset. Tampere: Vastapaino, 17-47.

Jokinen, A. \& Juhila, K. (1993). Valtasuhteiden analysoiminen. Teoksessa A. Jokinen, K. Juhila \& E. Suoninen Diskurssianalyysin aakkoset. Tampere: Vastapaino, 75-108.

Jokinen, A. (2006). Vakuuttelevan ja suostuttelevan retoriikan analysoiminen. Teoksessa A. Jokinen, K. Juhila \& E. Suoninen Diskurssianalyysi liikkeessä. Tampere: Vastapaino, 126-159.

Juhila, K. (2006). Kulttuurin jatkuvasti rakentuvat kehät. Tilanteisesta kulttuuriseen kontekstiin. Teoksessa A. Jokinen, K. Juhila \& E. Suoninen Diskurssianalyysi liikkeessä. Tampere: Vastapaino, 160-198.

Kiilakoski, T. \& Hautakangas, S. (2007). Huomenna hän oppii. niin \& näin, 1(52), 75-81.

Kinnari, H. (2009). Hyvän ja Pahan Tiedon Puu? Elinikäisen oppimisen rakentuminen Helsingin Sanomien mielipide- ja vieraskynäsivustoilla. Turun yliopisto. Kasvatustieteiden tiedekunta. Kasvatustieteen laitos. Pro Gradu. Viitattu http://www.doria.fi/bitstream/handle/10024/59104/ gradu2009kinnari.pdf?sequence=1

Kunelius, R. (1997). Viestinnän vallassa. Johdatusta joukkoviestinnän kysymyksiin. Helsinki: WSOY.

Nicoll, K. \& Fejes, A. (2008). Mobilizing Foucault in studies of lifelong learning. Teoksessa Fejes, A \& Nicoll, K (toim.) Foucault and lifelong learning. Governing the subject. London: Routledge, 1-18.

Olssen, M. (2008). Understanding the mechanisms of neoliberal control. Lifelong learning, flexibility and knowledge capitalism. Teoksessa Fejes, A \& Nicoll, $\mathrm{K}$ (toim.) Foucault and lifelong learning. Governing the subject. London: Routledge, 34-47.

Rinne, R. \& Salmi, E. (2000). Oppimisen uusi järjestys. Uhkien ja verkostojen maailma koulun ja elämänmittaisen opiskelun haasteena. Tampere: Vastapaino.

Rose, N. \& Miller, P. (2010). Miten meitä hallitaan. Suom. Risto Suikkanen. Tampere: Vastapaino.

Rose, N. (1998). Vallan ja vapauden välissä: Hyveen hallinta vapaassa yhteiskunnassa. Suom. Kalle Haatanen. Janus, 6(1), 1-33.

Rubenson, K. (2006). The Nordic model of Lifelong Learning. Compare, 36(3), 327-341.

Räsänen, P. (2007). Uusliberalismi ja lupaus vapaudesta. niin \& näin, vol 4, 99-107.

Saari, A. (2006). Elinikäisen oppimisen panopticon. Aikuiskasvatus, 26(4): 296-304.

Schuetze, H.G. (2006). International concepts and agendas of Lifelong Learning. Compare, 36(3). 289-306.

Silvennoinen, H. (2011). Aikuiskoulutus ja hallintavalta. Teoksessa Eteläpelto, A., Heiskanen, T. \& Collin, K. Valta ja toimijuus aikuiskasvatuksessa. Aikuiskasvatuksen 49. vuosikirja. Vantaa: Kansanvalistusseura, 55-76.

Suhonen, P. (1994). Mediat, me ja ympäristö. Helsinki: Hanki ja jää.

Suoninen, E. (2006). Näkökulmia sosiaalisen todellisuuden rakentumiseen. Teoksessa A. Jokinen, K. Juhila \& E. Suoninen Diskurssianalyysi liikkeessä. Tampere: Vastapaino, 17-36.

Tuomisto, J. (1994). Elinikäinen kasvatus - aatteesta strategiaksi. Teoksessa Kajanto, A. \& Tuomisto, J. Elinikäinen oppiminen. Vapaan sivistystyön 35. vuosikirja. Helsinki: Kirjastopalvelu Oy, 49-84.

Tuomisto, J. (1994). Elinikäisen oppimisen muodot teoreettiset lähtökohdat ja käytäntö. Teoksessa Kajanto, A. \& Tuomisto, J. Elinikäinen oppiminen. Vapaan sivistystyön 35. vuosikirja. Helsinki: Kirjastopalvelu Oy, 13-45.

Tuomisto, J. (2012). Elinikäinen oppiminen: oikeus vai pakko? Teoksessa Kettunen, P. \& Simola, H. Tiedon ja osaamisen Suomi. Kasvatus ja koulutus Suomessa 1960-Luvulta 2000-luvulle. Suomen Kirjallisuuden Seura: Helsinki, 411-435.

\section{Viitatut tekstit}

Viestintätaitojen opiskelu on tärkeää. 25.5.2006. Mielipide. Harri Westermarck, neuvontaopin professori, Helsingin yliopisto.

Tulosjohtamisessa inmisestä ei ole väliä. 2.1.2006. Mielipide. Jukka Tavi.

Uudenlainen suhtautuminen työhön olisi tarpeen. 14.10.2006. Mielipide. Jukka Jonninen, valt. yo.

Onko työttömyys saavutettu olotila? 5.3.2006, Sunnuntai-numero. Mielipide. Työvalmentaja, HS julkaisee kirjoituksen poikkeuksellisesti nimimerkillä.

Työssäolo ei saa olla turhaa ajanhukkaa. 1.9.2006. Mielipide. Jukka Peltokoski, sosiologian tutkija, Jyväskylän yliopisto. 